recognition of women at risk for postnatal depression. Aust N Z $\mathcal{J}$ Obstet Gynaecol 2000;40:409-12.

5. Wickberg B, Tjus T, Hwang P. Using the EPDS in routine antenatal care in Sweden: a naturalistic study. F Reprod Infant Psychol 2005;23:33-41.

6. Cooper PJ, Murray L, Hooper R, West A. The development and validation of a predictive index for postpartum depression. Psychol Med 1996;26:627-34.

7. Honey KL, Bennett P, Morgan M. Predicting postnatal depression. 7 Affect Disord 2003;76:201-10.

8. Beck CT. Revision of the Postpartum Depression Predictors Inventory. $7 \mathrm{Ob}$ stet Gynecol Neonatal Nurs 2002;31:394-402.

9. Cox J, Holden J, Sagovsky R. Detection of postnatal depression: development of the 10-item Edinburgh Postnatal Depression Scale. Br 7 Psychiatry 1987; 150:782-6.

10. Murray D, Cox JL. Screening for depression during pregnancy with the Edinburgh Postnatal Depression Scale (EPDS). 7 Reprod Infant Psychol 1990;8: 99-107.

11. American Psychiatric Association. Diagnostic and statistical manual of mental disorders. 4th ed. Washington: The Association; 1994.

12. Austin MP. Psychosocial assessment and management of depression and anxiety in pregnancy. Aust Fam Physician 2003;32:119-26.

13. Matthey S, Phillips J, White T, Glossop P, Hopper U, Panasetis P, et al. Routine psychosocial assessment of women in the antenatal period: frequency of risk factors and implications for clinical services. Arch Women Ment Health 2004;7:223-9.

14. Matthey S, White T, Phillips J, Taouk R, Chee TT, Barnett B. Acceptability of routine antenatal psychosocial assessments to women from English and non-English speaking backgrounds. Arch Women Ment Health 2005 May 27 [Epub ahead of print]

15. Beck CT. Recognizing and screening for postpartum depression in mothers of NICU infants. Adv Neonatal Care 2003;3:37-46.

16. Hanna B, Jarman H, Savage S, Layton K. The early detection of postpartum depression: midwives and nurses trial a checklist. 7 Obstet Gynecol Neonatal Nurs 2004;33:191-7.

17. Carroll JC, Reid AJ, Biringer A, Midmer D, Glazier RH, Wilson L, et al. Effectiveness of the Antenatal Psychosocial Health Assessment (ALPHA) form in detecting psychosocial concerns: a randomized controlled trial. CMA7 2005;173(3):253-9.

18. Shakespeare J; National Screening Committee (NSC). Evaluation of screening for postnatal depression against the NSC handbook criteria. London: The Committee; 2001. Available: http://libraries.nelh.nhs.uk/common/download .asp? resourceID=60971 (accessed $2005 \mathrm{Jul} 4)$.

Correspondence to: Dr. Stephen Matthey, Sydney South West Area Health Service: Infant, Child and Adolescent Mental Health Service, George St. Health Centre, 157-161 George St., 2nd Floor, Liverpool NSW 2170, Australia; fax (02) 8778 0768; stephen.matthey@swsahs.nsw.gov.au

\title{
Supreme Court slaps for-sale sign on medicare
}

\section{Lawrie McFarlane}

Published at www.cmaj.ca on June 20, 2005.

ß See related articles pages 271, 273, 275 and 277

I n 1857 the US Supreme Court issued its now-infamous Dred Scott judgment, decreeing that the constitutional guarantee of equal treatment under the law did not apply to slaves. The decision by Canada's Supreme Court on June 9, 2005, to permit private health insurance in Quebec ${ }^{1}$ - and by implication, in the rest of the country - is a moment of comparable judicial folly, for it effectively sets aside a statutory protection of no less significance.

In Canada, every citizen is assured reasonable and equal access to publicly funded health services without regard to class or income. The Canada Health Act permits only one test: medical necessity. The Supreme Court's decision implicitly adds a second, and many fear pre-emptive, test: financial status. As counsel for one of the appellants in the original trial made clear, "I am arguing for the right of more affluent people to have access to parallel health corvices."

For defenders of universal health care, the court's rea$\ddot{*}$ soning is stultifying. The case before the justices amounted A to this: a Quebec resident needed orthopedic surgery and was required, because of backlogs in treatment, to wait longer than appropriate. On that basis, he argued he should have access to a separate, private system.

There is no dispute that lengthy wait times cause pain and diminished quality of life. Everyone agrees that delays are unacceptably long in parts of the country. Yet before the court imposed its radical solution, it might have taken more care in its consideration of the nature of the problem.

There are a variety of reasons for lengthening wait lists. Some certainly relate to funding shortfalls or poor management practices. But an equal part of the trend can be linked to excessive compensation demands by various health professions, and to the failure of some medical specialists to practise within appropriate clinical guidelines. Introducing private medicine will not address these problems, and may in fact exacerbate them.

More importantly, the wait-list problem is confined mainly to a narrow, albeit essential, area of medical practice. With a few region-specific exceptions, such as radia- 
tion therapy in Quebec, most of the concern focuses on elective surgery, and more narrowly still, on orthopedic surgery.

Consider the following growth rates for surgical procedures in British Columbia between 1995 and 2000:

- gynecologic procedures: $4 \%$

- urological surgery: $7.7 \%$

- neurosurgery: $8 \%$

- hip replacement: $42 \%$

- cataract surgery: $66 \%$

- knee replacement: $92 \%$

These figures (and similar rates of increase apply in most of the country) illustrate a critical aspect of the dilemma. Wait times have increased because of an unprecedented surge in procedure volumes. Because this increase exceeds population growth or demographic change by several orders of magnitude, it seems that other causes must be in-

\section{Forty years of labour have been cast aside in a spasm of judicial intemperance, and a radical, if not catastrophic, remedy has been imposed to solve a narrow and probably transitory problem.}

volved. The advent of less invasive surgical procedures, enabling patients to be discharged from hospital more quickly, is likely a critical factor.

Given a chance, our health care system will adapt to this changing demand, as it has adapted in the past to other challenges. Six months ago the federal and provincial governments signed a joint Health Accord to attack surgical delay and other related difficulties. One might have hoped the court would allow that initiative time to work before throwing judicial restraint to the wind. At a minimum, whatever remedy was adopted to correct such a narrowly located problem should have been proportionately narrow in its application. Instead, Madame Justice Marie Deschamps, writing for the majority, imposed a sweeping remedy that has the potential to reorder not only orthopedic care but the entire health care spectrum, from family medicine to surgery to acute hospital care.

Critics might wonder why the court doesn't swallow a dose of its own medicine. The problem of trial delay in the judicial field dwarfs whatever difficulties confront our health service. Nation wide, well over half of all criminal cases exceed the guideline, set down by the Supreme Court, of 8 months from arraignment to the start of trial. Many cases take 2 or even 3 times that long. Would the court accept the argument that a parallel judicial system should be created for the well-heeled, to save them the evils of trial delay? Of course not, but it bears thinking why. We have only one court system for the same reason we have only one health care system: the principle of equal treatment demands it. A dual court system would be unthinkable in the same way that two-tier medicine should be unthinkable. (Interestingly, when the issue of trial delay arises, judges apply exactly the same types of remedy as the Supreme Court has now denied the health care system: they ask government for more resources, set guidelines for appropriate wait times and plead for patience when they come up short.)

Madame Justice Ginette Piché of the Quebec Superior Court, whose judgment the Supreme Court overturned, made the link between health care and other basic rights explicit in her decision: "The Court ... considers that if access to the health system is not possible, it is illusory to think that rights to life and security are respected." ${ }^{3}$

In other words, health care is not some commodity to be bartered on the open market. Rather, it is a precondition of the basic rights guaranteed by the Charter. That being so, it should enjoy the same protection, meaning that it must be provided on an equal and indivisible basis.

Had the justices accepted this reasoning, other remedies were at hand. It lay within the court's power to order an improvement in surgical wait lists within the public system, up to some required standard. Perhaps with the imminent threat of a two-tier system to clarify their thinking, the provinces would have made the necessary reforms.

Instead, as the implications sink in, health ministries across the country are aghast. No one has a clue where we go from here. Forty years of labour have been cast aside in a spasm of judicial intemperance, and a radical, if not catastrophic, remedy has been imposed to solve a narrow and probably transitory problem.

The drafters of the Dred Scott judgment thought they had ensured the perpetuation of an underclass in American society, but in fact the opposite came to pass. People were scandalized when they saw such unworthy sentiments dignified in legal reasoning, and in less than a decade, slavery was abolished.

Defenders of medicare can only hope the same thing happens here, and that as people realize the Supreme Court has disfigured a national symbol, they will sweep away two-tier medicine once and for all.

Lawrie McFarlane was a deputy minister of health for British Columbia and chief executive officer of Saskatchewan's first regional health authority. He writes on public policy.

Competing interests: None declared.

\section{References}

\footnotetext{
1. Chaoulli v. Quebec (Attorney General). 2005 SCC 35.

2. Chaoulliv. Quebec (Attorney General) [2000] JQ no 479 at 7.

3. Chaoulliv. Quebec (Attorney General) [2000] JQ no 479 at 138.
}

Correspondence to: Lawrie McFarlane, 5071 Delmonte Ave., Victoria BC V8Y1W9; jalmcfarlane@shaw.ca 